\title{
Cycloaddition of Allyl Radical to Methylacetylene
}

\author{
Daisuke Nohara* and Tomoya SAKaI*
}

\begin{abstract}
The reaction of allyl radical with methylacetylene was carried out at $450-510^{\circ} \mathrm{C}$, employing diallyl oxalate as a source of the allyl radical. Addition products of allyl radicals to methylacetylene were three methylcyclopentadiene isomers, cyclopentadiene, 1,4-hexadiene and 2methyl-1,4-pentadiene, and they corresponded well to those produced in the reaction of the allyl radical with propylene. The high product ratio of cyclic addition products to those of acyclic was characteristic of the reaction with acetylenes in contrast to the reaction with olefins. The second-order rate constant, activation energy and $A$ factor for the formation of $\mathrm{C}_{5}$-cyclic products were evaluated based on the estimated concentrations of allyl radicals in situ from the amount of biallyl formed simultaneously in the same reaction system. It was revealed that both the activation energy and the $A$ factor for the formation of $\mathrm{C}_{5}$-cyclic products, as well as the observed second-order rate constant, were larger in the reaction with acetylenes than that with olefins.
\end{abstract}

\section{Introduction}

The allyl radical has been shown to take the role of diene in the cyclization reaction with ethylene $^{1)}$, acetylene ${ }^{2)}$ or propylene ${ }^{3)}$. In those studies, biallyl and diallyl oxalate (DAO) have been used as sources of allyl radicals. The use of DAO, in particular, enabled us to estimate the concentrations of allyl radicals present in the reaction system from the amount of biallyl concurrently formed in the same reaction system. Thus, it has become possible to evaluate the secondorder rate constants of reactions involving allyl radicals. The addition products of allyl radicals to ethylene were nearly equimolar amounts of cyclopentene and 1-pentene. In the reaction of allyl radicals with propylene, two methylcyclopentene isomers, methylcyclopentane, 1-hexene and 4-methylpentene were produced. In the reaction of allyl radicals with acetylene, on the other hand, cyclopentadiene was formed with selectivity higher than 90 percent.

The second-order rate constant for the formation of $\mathrm{C}_{5}$-cyclic products was found larger in the reaction with acetylene than with ethylene and with propylene.

In the present work, the reaction of methylacetylene with the allyl radical has been examined. It is revealed that both high selectivity and large rate constants for cycloaddition as in the case of

Received March 17, 1980.

* Department of Chemical Reaction Engineering, Faculty of Pharmaceutical Sciences, Nagoya City University. (3-1, Tanabe-dori, Mizuho-ku, Nagoya 467) acetylene, was valid although the cycloaddition products in the present case include three methylcyclopentadiene isomers and cyclopentadiene.

\section{Experimental}

The apparatus was of an ordinary atmospheric flow system equipped with a reactor made of quartz annular cylinder. Details of the apparatus and procedures were described in our previous communications $\mathbf{s}^{1) \sim 3)}$.

Methylacetylene was diluted with deoxygenated nitrogen to a concentration of $1.6 \mathrm{vol} \%$. Such dilution was found indispensable for preventing polymerization of the substrate. Impurities in methylacetylene were ca. $5 \mathrm{~mol} \%$ acetylene and $0.5 \mathrm{~mol} \%$ allene. DAO was introduced with a microfeeder to the evaporator placed ahead of the reactor and was mixed in the flowing methylacetylene- $\mathrm{N}_{2}$ gas. The concentration of DAO vapor was adjusted to about $2.5 \mathrm{vol} \%$ of the total inlet gas.

Reactants and products were analyzed with FID and TCD gas chromatographs and with GC-MS. Reaction temperatures and residence times were between 450 and $510^{\circ} \mathrm{C}$ and between 3 and $16 \mathrm{~s}$, respectively. The equivalent reactor volume at each designated temperature was calculated by the method of Hougen and Watson ${ }^{4}$.

\section{Results and Discussion}

\subsection{Products}

DAO was stoichiometrically pyrolyzed to allyl radicals and carbon dioxide. The rate of decomposition of DAO measured by the amount of 
Table 1 Typical Experimental Data

\begin{tabular}{|c|c|c|c|c|c|c|c|c|}
\hline \multirow{3}{*}{$\begin{array}{l}\text { Temperature }\left({ }^{\circ} \mathrm{C}\right) \\
\text { Residence time }(\mathrm{s}) \\
\text { DAO conversion }(\%)\end{array}$} & \multicolumn{2}{|c|}{510} & \multicolumn{2}{|c|}{490} & \multicolumn{2}{|c|}{470} & \multicolumn{2}{|c|}{450} \\
\hline & 7.08 & 3.45 & 7.25 & 3.48 & 7.91 & 3.83 & 8.05 & 3.89 \\
\hline & 31.8 & 15.0 & 14.5 & 7.17 & 7.31 & 2.21 & 2.64 & 0.905 \\
\hline \multicolumn{9}{|l|}{ Products $\left(10^{-10} \mathrm{~mol} \cdot \mathrm{cm}^{-3}\right)$} \\
\hline Methane & 12.4 & 6.70 & 5.63 & 3.17 & 3.24 & 1.13 & 1.49 & 0.69 \\
\hline Ethylene & 64.6 & 29.7 & 28.7 & 15.2 & 18.0 & 6.50 & 8.15 & 4.09 \\
\hline Propylene & 508 & 254 & 267 & 141 & 152 & 57.5 & 61.3 & 27.8 \\
\hline Allene & 24.3 & 15.8 & 10.4 & 3.77 & 1.77 & 1.17 & 0.87 & 0.23 \\
\hline 1-Butene & 22.9 & 8.51 & 10.0 & 3.39 & - & 0.97 & 0.94 & 0.25 \\
\hline & $\begin{array}{c}21.6 \\
(28.7)\end{array}$ & $\begin{array}{r}7.70 \\
(11.2)\end{array}$ & $\begin{array}{r}8.16 \\
(11.0)\end{array}$ & $\begin{array}{c}2.94 \\
(3.50)\end{array}$ & $\begin{array}{c}3.86 \\
(5.22)\end{array}$ & $\begin{array}{c}1.05 \\
(1.71)\end{array}$ & $\begin{array}{c}1.42 \\
(1.90)\end{array}$ & $\begin{array}{c}0.57 \\
(0.81)\end{array}$ \\
\hline 1,4-Hexadiene & 11.3 & 6.84 & 7.03 & 3.66 & 3.74 & 1.61 & 1.35 & 0.66 \\
\hline Biallyl & 3,060 & 1,310 & 1,100 & 459 & 580 & 188 & 180 & 77.6 \\
\hline & 9.46 & 4.13 & 4.36 & 1.31 & 1.64 & 0.51 & 0.39 & 0.27 \\
\hline & 41.4 & 17.2 & 12.7 & 6.49 & 7.36 & 2.97 & 2.95 & 1.01 \\
\hline & 34.3 & 14.6 & 11.1 & 5.23 & 5.67 & 2.30 & 2.24 & 0.82 \\
\hline$\overline{2-\mathrm{Me}}-1,4$-pentadiene & 6.66 & 2.08 & 1.57 & 0.39 & 0.71 & $\operatorname{tr}$ & $\operatorname{tr}$ & $\operatorname{tr}$ \\
\hline
\end{tabular}

Amounts of cyclopentadiene are the revised amounts as described in the text ; in parentheses are the observed amounts.

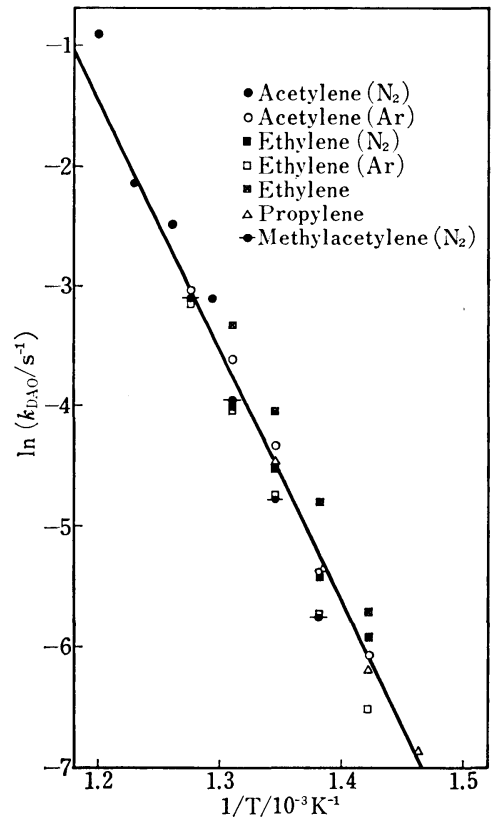

Fig. 1 Arrhenius Plots for the DAO Decomposition in the Presence of Unsaturated Hydrocarbons

carbon dioxide fitted the first-order rate law. By combining the results of our previous works ${ }^{1) \sim 3}$, the rate of DAO decomposition can be summarized as illustrated in Fig. 1, and its rate constant is now defined as:

$$
k=10^{10.8} \exp (-180,000 / \mathrm{RT}) \mathrm{s}^{-1}
$$

Products in the reaction of DAO with methylacetylene were three methylcyclopentadiene isomers, 1,4-hexadiene, 2-methyl-1,4-pentadiene and cyclopentadiene, in addition to a large amount of biallyl

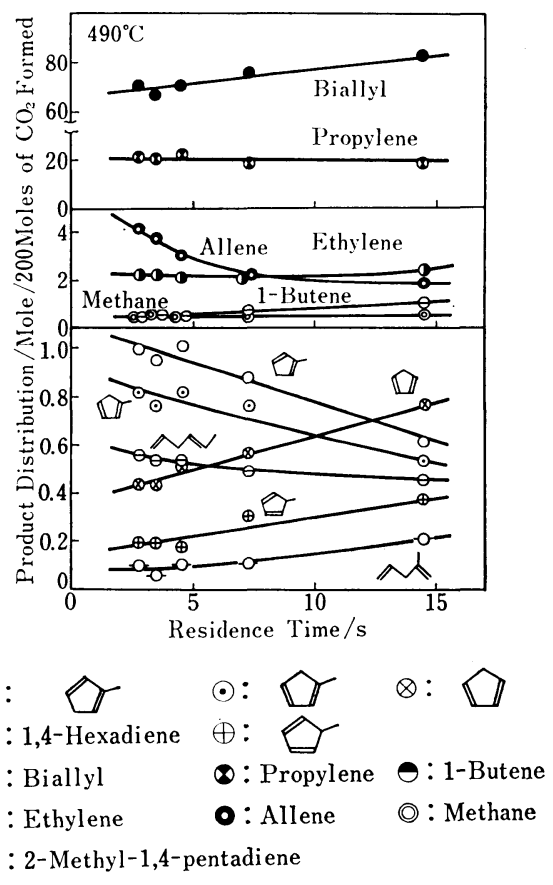

Fig. 2 Product Distribution against Residence Time

presumably resulted from recombination of allyl radicals, and propylene, ethylene, 1-butene, allene and methane.

Typical experimental results are listed in Table $\mathbf{I}$ and the product distribution obtained at $490^{\circ} \mathrm{C}$ is shown in Fig. 2. Three methylcyclopentadiene isomers are tentatively assigned to be and in the decreasing order of their amounts 
since they could not be identified-individually even by GC-MS. Butadiene, which is likely to be produced in this system, as well as in the previous cases ${ }^{1) ~ 3)}$, could not be detected presumably due to its overlapping with the intense methylacetylene peak in the gas chromatogram.

The amounts of the main products are plotted against residence time in Fig. 3. The main addition products correspond well to those observed in the reaction with propylene, i.e., three methylcyclopentadiene isomers corresponding to two methylcyclopentene isomers, and 1,4-hexadiene to 1hexene, and 2-methyl-1,4-pentadiene to 4-methylpentene. However, no hydrogenated cyclic compound such as methylcyclopentane or methylcyclopentene was found in the present reaction in contrast to the result obtained in the reaction with propylene ${ }^{3)}$.

The major portion of the cyclopentadiene formed in the present reaction should be accounted for by addition of an allyl radical to methylacetylene. It might be argued that cyclopentadiene could be formed through the reaction of an allyl radical with acetylene ${ }^{2), 5)}$, which was present as an impurity of methylacetylene. But the amount of cyclopentadiene through this latter reaction is esti-

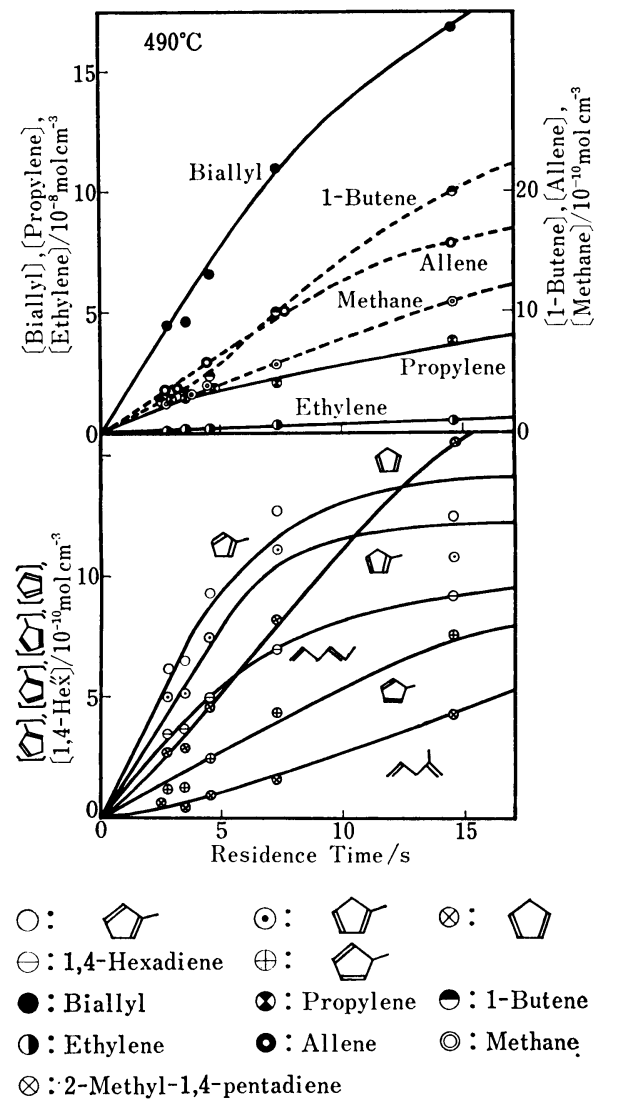

Fig. 3 Product Formation against Residence Time mated to be at most $20 \sim 30$ mole percent of the cyclopentadiene observed based on the $k$-value reported in our previous experiment with acetylene ${ }^{2)}$. The amounts of cyclopentadiene in Table 1 and Figs. 2 and $\mathbf{3}$ are those corrected for the reaction of the acetylene impurity.

\subsection{Proposed Reaction Scheme}

First, DAO is pyrolyzed to allyl radicals and carbon dioxide in Reaction (1).

$$
\mathrm{DAO} \longrightarrow 2 \mathrm{C}=\mathrm{CC} \cdot+2 \mathrm{CO}_{2}
$$

Most of the allyl radicals recombine to produce biallyl in Reaction (2).

$$
2 \mathrm{C}=\mathrm{CC} \cdot \longrightarrow \mathrm{C}=\mathrm{CCCC}=\mathrm{C}
$$

Reaction (2) is used as a reference reaction to estimate the concentrations of allyl radicals in situ in the present reaction system. The allyl radical abstracts hydrogen to produce propylene in Reaction (3).

$$
\mathrm{C}=\mathrm{CC} \cdot+\mathrm{RH} \longrightarrow \mathrm{C}=\mathrm{CG}+\mathrm{R} \text {. }
$$

Any $\mathrm{H}$-donor, such as DAO and methylacetylene which exist in high concentrations in the system, can act as RH in Reaction (3). As to the addition of the allyl radical to methylacetylene, two types shown in Reaction (4) may be considered.

$$
\mathrm{C}=\mathrm{CG} \cdot+\mathrm{G} \equiv \mathrm{CG} \longrightarrow \mathrm{i}^{\prime},
$$

Of the above, the terminal addition should take place in preference to the other. Both cyclize to produce methylcyclopentenyl radical in Reaction (5).

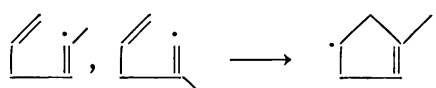

The methylcyclopentenyl radical formed in $\mathrm{Re}$ action (5) eliminates hydrogen to produce three methylcyclopentadiene isomers, the main cycloaddition products, through Reactions (6), (7), (8) and (9).

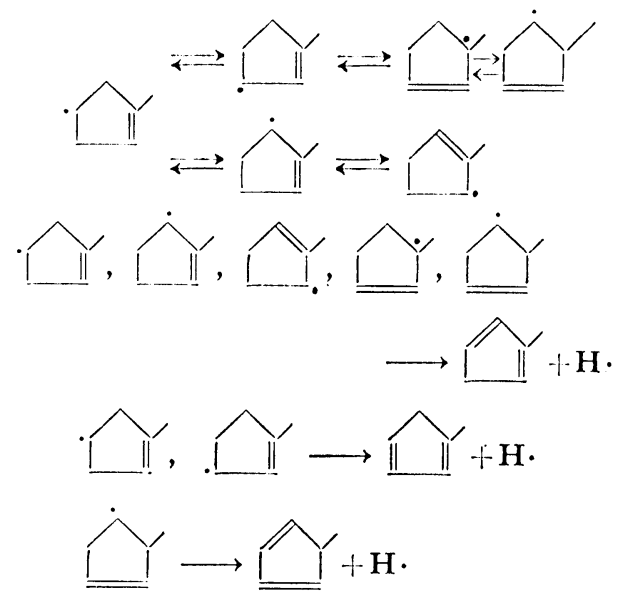

Cyclopentadiene might be formed through Reaction 
(10).

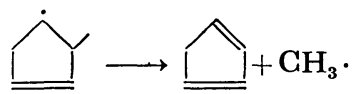

The methyl radical thus produced either abstracts hydrogen to form methane or adds to the unsaturated species to form a variety of minor products.

On the other hand, the radicals formed in Reaction (4) abstract hydrogen in Reactions (11) and (12) to produce acyclic compounds such as 1,4-hexadiene and 2-methyl-1,4-pentadiene.

$$
\stackrel{N}{\prime}+\mathrm{RH} \longrightarrow \mathrm{N} / \mathrm{R} \text {. }
$$

1-Hexene-4-ynes were not found in the product; this was consistent with our previous works ${ }^{2), 3)}$ in that no acyclic compound could have been formed through hydrogen atom elimination.

Schemes for the formations of 1-butene and ethylene are considered to be the same as those in the previous acetylene case ${ }^{2}$ ) since the amount produced did not differ greatly from that resulted previously. Thus, a part of biallyl produced decomposes as $\mathbf{G}=\mathbf{C C C G}=\mathbf{G} \rightarrow \mathbf{C}=\mathbf{C} \cdot+\mathbf{C}=\mathbf{C C G} \cdot$, and the radicals formed abstract hydrogen to produce ethylene and 1-butene, or eliminate hydrogen from a 3-butenyl radical to yield butadiene although the latter could not be measured in the present experiment. The formation of allene is attributable to the radical, $\mathrm{C} \equiv \mathrm{CC} \cdot$, which isomerizes in Reaction (13) and abstracts hydrogen to produce allene in Reaction (14).

$\mathrm{C} \equiv \mathrm{CC} \cdot \rightleftarrows \mathrm{G}=\mathrm{C}=\mathrm{C}$.

$\mathrm{C}=\mathrm{C}=\mathrm{C} \cdot+\mathrm{RH} \longrightarrow \mathrm{C}=\mathrm{C}=\mathrm{C}+\mathrm{R}$.

The amount of methane formation was nearly equal to that of cyclopentadiene formation. Moreover, the production profiles of both methane and cyclopentadiene in Fig. 3 resemble each other. Thus, it is appropriate to assume that methane and cyclopentadiene are formed in the course of isomerization of methylcyclopentenyl radical in Reaction (6) and demethylation in Reaction (10).

\subsection{Kinetics}

The second-order rate constant, $k$, for the formation of each product can be obtained by the same treatment used in our previous works ${ }^{1), 2}$. Thus, for example, the characteristic rate constant can be assigned to a series of Reactions (4) $\sim(9)$ as shown below:

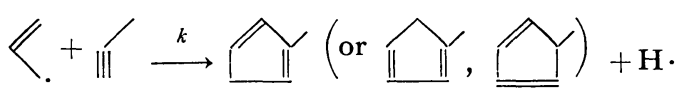

1,4-Hexadiene, 2-methyl-1,4-pentadiene and cyclo- pentadiene are also tentatively regarded as originating from the allyl radical and methylacetylene with the rate relevant to each reaction. The equation used for calculating $k$-values is as follows: $d[$ product $] / d t=k[$ allyl $\cdot][\mathrm{C} \equiv \mathrm{CG}]$

Concentrations of allyl radicals in the system at each reaction temperature can be estimated from the equation below based on the experimentally obtained rate of biallyl formation and $k_{2}$-value of Reaction (2) taken from literature ${ }^{6), 7)}$. $d[$ biallyl $] / d t=k_{2}[\text { allyl } \cdot]^{2}$

The rate, $d$ [product]/dt or $d$ [biallyl] $/ d t$, is evaluated from the initial slope of the experimentally observed curve as shown in Fig. 3 for the case at $490^{\circ} \mathrm{C}$.

The temperature dependence of the $k$-values is illustrated in Fig. 4, and the corresponding kinetic parameters are listed in Table 2 together with those obtained in our previous works ${ }^{1), 2)}$. The activation energies for the formations of and are obtained as 100, 102, 107, and $117 \mathrm{~kJ} \mathrm{~mol}^{-1}$, respectively. The last value may be in somewhat larger error since the amount of this last isomer was relatively small. The activation energy for overall $\mathrm{C}_{5}$-cyclic products formation,

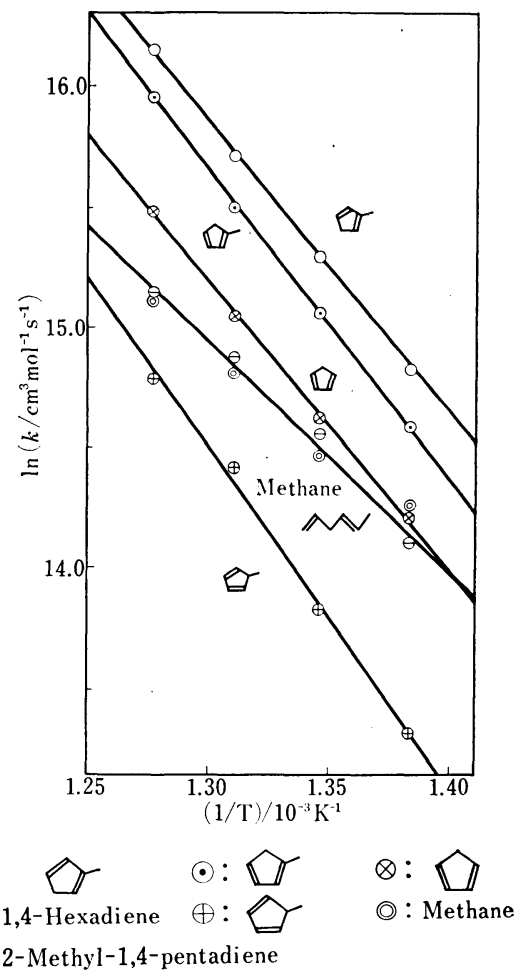

Fig. 4 Temperature Dependency of $k$-Value for Each Product Formation 
Table 2 Kinetic parameters

\begin{tabular}{|c|c|c|c|c|}
\hline \multirow[b]{2}{*}{ Reaction } & \multirow[b]{2}{*}{ Product } & $\log _{10} k_{500^{\circ} \mathrm{C}}$ & $E$ & $\log _{10} A$ \\
\hline & & $\left(\begin{array}{l}\mathrm{cm}^{3} \cdot \mathrm{mol}^{-1} \cdot \\
\mathrm{s}^{-1}\end{array}\right)$ & $\left(\begin{array}{l}\mathrm{kJ} \cdot \\
\mathrm{mol}-1\end{array}\right)$ & $\left(\begin{array}{l}\mathrm{cm}^{3} \cdot \\
\mathrm{mol}^{-1} \\
\mathrm{~s}^{-1}\end{array}\right)$ \\
\hline \multirow{6}{*}{$\begin{aligned} & \mathrm{C}=\mathrm{C}-\mathrm{C} . \\
&+ \\
& \mathrm{C} \equiv \mathrm{C}-\mathrm{C}\end{aligned}$} & & 6.97 & 102 & 13.9 \\
\hline & & 6.89 & 107 & 14.1 \\
\hline & & 6.35 & 117 & 14.3 \\
\hline & & 6.61 & 100 & 13.4 \\
\hline & & 6.51 & 80.3 & 11.9 \\
\hline & & 6.17 & - & - \\
\hline \multirow{2}{*}{$\begin{array}{c}\mathrm{C}=\mathrm{C}-\mathrm{C} . \\
+ \\
\mathrm{C}=\mathrm{C}\end{array}$} & & 6.52 & 48.0 & 9.77 \\
\hline & & 6.38 & 69.8 & 11.1 \\
\hline $\begin{array}{c}\mathrm{C}=\mathrm{C}-\mathrm{C} . \\
+ \\
\mathrm{C} \equiv \mathrm{C}\end{array}$ & & 7.64 & 104 & 14.6 \\
\hline
\end{tabular}

$105 \mathrm{~kJ} \mathrm{~mol}^{-1}$, coincides with the value of 104 $\mathrm{kJ} \mathrm{mol}^{-1}$ found for cyclopentadiene formation in the reaction with acetylene ${ }^{2}$. The numerical similarity of the activation energy of $100 \sim 110 \mathrm{~kJ} \mathrm{~mol}^{-1}$ and the $A$ factor of 1013) 14) obtained for the formations of methylcyclopentadienes and cyclopentadiene suggests that a similar rate-limiting step governs their formations.

From the above discussions, the characteristic feature for $\mathrm{C}_{5}$-cyclic products formation through addition of the allyl radical to unsaturated hydrocarbons was revealed that both the activation energy and the $A$ factor are larger for the acetylenic systems than for the olefinic systems. The activation energy for the formation of 1,4-hexadiene, $80.3 \mathrm{~kJ} \mathrm{~mol}^{-1}$, is lower than that for the formation of $\mathrm{C}_{5}$-cyclic products. This fact indicates that the rate-limiting step for the cyclic products formation is not in the allyl addition step, Reaction (4), which is common to the formations of both cyclic and acyclic products, but either in the cyclization step of an intermediate acyclic radical or in the hydrogen atom elimination step from methylcyclopentenyl radical.

\section{References}

1) Sakai, T., Nohara, D., Kunugi, T., "ACS Symp. Ser., Industrial and Laboratory Pyrolyses", 32, 152 (1976).

2) Nohara, D., Sakai, T., Ind. Eng. Chem., Fundam., 19, (4), 340 (1980).

3) Sakai, T., Nohara, D., Oral Presentation, 7th Sekiyu Kagaku Toronkai, 3D01 (1976).

4) Hougen, D. A., Watson, K. M., "Chemical Process Principles", 884 (1943), Wiley, New York, N.Y.

5) Nohara, D., Sakai, T., J. Japan Petrol. Inst., 23, (2), 133 (1980).

6) Golden, D. M., Gac, N. A., Benson, S. W., J. Am. Chem. Soc., 91, 2136 (1969).

7) Rossi, M., King, K. D., Golden, D. M., J. Am. Chem. Soc., 101, 1223 (1979). 
要 旨

\section{アリルラジカルのメチルアセチレンへの環化的付加}

野 原大 輔*, 酒 井朝 也*

ジアリルオギザレート (DAO) をアリルラジカル生成源とし て用い, アリルラジカルとメチルアセチレンの反応を行った。 反応装置は常圧流通式のものであり, $\mathrm{N}_{2}$ 気流中 DAO 蒸気お よびメチルアセチレン濃度をそれぞれ 2.5 および $1.6 \mathrm{~mol} \%$ と した。反応温度は $450-510^{\circ} \mathrm{C}$, 滞留時間は $3-16 \mathrm{~s}$ であった。 $\mathrm{DAO}$ がアリルラジカルと $\mathrm{CO}_{2}$ に分解する反応は一次速 度式として整理でき，一次速度定数のアレニウスプロットを Fig. 1 に示した。アリルラジカルとメチルアセチレンの反応 の主要生成物とそれらの生成量を Table 1 に, 生成物分布を Fig. 2 に示した。アリルラジカルがメチルアセチレンに付加し てできた生成物として, 三つのメチルシクロペンタジェン異性 体，シクロペンタジェン， 1,4-ヘキサジェン，2-メチル-1, 4ペンタジェンが得られた。この他に, DAO を用いた反応の特 徵として大量のビアリルが生成し, さらにプロピレン, エチレ ン，1ーブデン，アレンおよびメタンが生成した。

既報2)のアリルラジカルとアセチレンの反応結果と同様, ア リルラジカルの付加によって生成する $\mathbf{C}_{5}$ 環状化合物の量が非 環状付加生成物の量を大きく上回った。これは既報1)のアリル ラジカルとェチレンの反応でシクロペンテンと1-ペンテンがほ ぼ 1:1 で生成した結果と対比され, アセチレン化合物の反応 の特徵といえよう。

主要生成物生成のスキームを提示し，このスキームに基づい てアリルラジカルがメチルアセチレンに付加してできる各生成 物について二次反応速度定数を求めた。その際用いたアリルラ ジカル濃度は系中で同時に進行するアリルラジカルの再結合反

* 名古屋市立大学薬学部 (467 名古屋市瑞穂区田辺通 3-1)
応すなわちビアリルの生成速度から推算した。各着目生成物に 対する二次反応速度定数の温度依存性を Fig. 4 に示した。活 性化エネルギー, $A$-factor および $500^{\circ} \mathrm{C}$ に拈ける速度定数を 既報のアリルラジカルがェチレンに付加してできるシクロペン テンおよび1-ペンテン，さらに，アセチレンとの反応における シクロペンタジェンの生成について得られた值とともに Table 2 に示した。

DAO を用いたアリルラジカルとアセチレンの反応に拈ける シクロペンタジェン生成に対する活性化エネルギーは $104 \mathrm{~kJ}$. mol-1 であった。今回の反応における $\mathrm{C}_{5}$ 環状化合物生成に対 する活性化ェネルギーは $105 \mathrm{~kJ} \cdot \mathrm{mol}^{-1}$ と求まり, 両者はよく一 致した。また，1,4一へキサジェン生成に対して求まった 80.3 $\mathrm{kJ} \cdot \mathrm{mol}^{-1}$ の活性化エネルギーはアリルラジカルとェチレンの 反応に批る 1-ペンテン生成の活性化エネルギー $69.8 \mathrm{~kJ}$. $\mathrm{mol}^{-1}$ に近い值であり, これはアルカジェニルラジカルの水素 引き抜き過程に対応していることを示している。今回の反応お よび既報のアリルラジカルとェチレンあるいはアセチレンとの 反応を総合して次の事がいえる。アリルラジカルがアセチレン 系炭化水素に付加してできる $\mathrm{C}_{5}$ 環状化合物の生成とェチレン に付加してできる $\mathrm{C}_{5}$ 環状化合物の生成とについて速度論的に 比較すると前者の方が後者よりも活性化エネルギーにおいて約 $50 \mathrm{~kJ} \cdot \mathrm{mol}^{-1}, A$-factor に打いて $10^{4-10^{5}}$ 倍そして $500^{\circ} \mathrm{C} に$ おける速度定数は約 10 倍大きいことが明らかとなった。また， 本反応系における $\mathrm{C}_{5}$ 環状化合物の生成に対して求まった活性 化エネルギーが反応経路の内のどの素過程に基づくものかを議 論した。

\section{Keywords}

Allyl radical, Kinetics, Methylacetylene, Cycloaddition, Methylcyclopentadiene 